\title{
No loss - or is there? The awkward case of the trustee's claim for damages
}

\author{
by Andrew Tettenborn
}

\begin{abstract}
"My Lords, my clients have no merits, but they are right." Thus, so legend has it, Kenneth Diplock KC boldly opened a large commercial case some years ago. But these words might equally apply to the plea dealt with here: namely, where a defendant admits breach of contract but then suavely denies liability to pay anything more than nominal damages on the basis that the loss has been suffered by someone other than the claimant. In the last three years a small congeries of cases has dealt with one aspect of this issue: namely, claims by a trustee or someone in a similar position. How far, if at all, is the person dealing with the trustee entitled to pray in aid the fact that the trustee (as opposed to the beneficiaries) has suffered no personal loss, in order to reduce or eliminate his own liability to that trustee?
\end{abstract}

I $n$ the first of these cases, Welburn $v$ Dibb Lupton Broomhead [2003] PNLR 28, the Court of Appeal in 2002 took what looked like the logical view, and held he was. The claimant allegedly had to write off a debt because the solicitors instructed to recover it dragged their feet, and meanwhile the debtor ceased trading. He sued the solicitors for professional negligence. But a complication arose: at the time of the alleged negligence the claimant himself had been subject to an individual voluntary arrangement, the effect of which was to transfer the beneficial interest in the unrecovered debt to his supervisor, leaving him with bare legal title to it.

The Court of Appeal, taking an apparently pragmatic line, agreed with the trial judge that even if the claimant could prove negligence, he had suffered no loss. He had merely been deprived of something he was not properly entitled to in any event: and the fact that because of the technicalities of insolvency law he had held a bare legal title to it was irrelevant given that the effective, beneficial title was elsewhere.

Welburn may seem logical: but the practical difficulty with it is not hard to see. If the claimant could not recover, it is by no means clear that the supervisor could sue either. After all, he had not instructed the solicitors; he thus would have to rely on a common law duty in tort, and this duty itself might be problematic, given the equitable nature of his interest. And if the supervisor could not sue, then the defendant's liability would simply have disappeared, point, or something like it, that informed Neuberger J some months later in another legal malpractice case, Chappell v Somers \& Blake [2004] Ch. 19. An executrix instructed solicitors to distribute the assets of the estate, including a couple of rental properties. Five years later nothing had happened, the properties stood empty, and the would-be legatee had received no rent. The executrix sued the solicitors for negligence, claiming the lost rentals. The solicitors riposted that the loss was the legatee's, and that this was no skin off the nose of the executrix, who was the person suing.

Neuberger J, in a careful judgment, had little hesitation in declining to allow the solicitors to rely on this fact and holding them liable to pay substantial damages. Wherever beneficial title might lie (a somewhat awkward question in the case of undistributed estates), the executrix's legal title should be regarded as sufficient to allow her to recover substantial damages on behalf of whoever might be entitled under the estate. It was, to say the least, doubtful whether the legatees could sue: and if they could not, then (echoing White v Jones [1995] 2 AC 207) it was clearly sound policy that someone should be able to.

Perhaps it is surprising that this point of the trustee's ability to recover never seems to have arisen, save in isolated dicta (eg. Lloyds v Harper (1880) 16 Ch.D 290) before Chappell. Nevertheless the result in that case, it is suggested, makes good sense. True, it technically amounts to giving a claimant damages for loss she has not ultimately suffered. But no injustice seems to have been done. And 
effectively by giving the trustee title to sue it means that we reach the result we want, namely that the defendant is treated as if liable to "the trust" or "the estate" (an abstract entity whose legal status is otherwise, to say the least, problematic). Moreover, Chappell has since been followed at first instance by Laddie $\mathrm{J}$ in a genuine trust case, deciding that the legal owner of trust assets can obtain substantial damages in conversion, just as he can recover for breach of contract: see Malkins Nominees Ltd $v$ Société Financière Mirelis SA [2004] EWHC 2631 (Ch).

Nevertheless, before one concludes that all is well, at least two problems arise. The first is the relation between Chappell and the earlier Welburn, which did allow the defendant to take the "no loss" point. The latter - a Court of Appeal decision, it will be remembered - was not cited in Chappell, or for that matter in Malkins; as a result both later decisions could, theoretically be dismissed as per incuriam. It is suggested, however, that to deny recovery to a claimant in the Chappell situation would be most unfortunate, and that in the event of conflict the courts will recognise this and try to distinguish Welburn. One possible ground is that Welburn involved an entirely passive trustee someone, indeed, whose legal ownership could rightly be called a historical technicality - whereas in Chappell the claimant was emphatically active: like any personal representative, she had considerable functions and responsibilities, and thus a real interest in the estate assets. But the active-passive distinction might be an awkward one to draw in practice.

More convincing and practical (it is suggested) is the fact that Welburn, unlike the later decisions, involved insolvency. In insolvency scenarios there is considerable advantage in ensuring that the correct person - that is, the party ultimately entitled to collect the insolvent's estate for his creditors, and not the insolvent himself - brings and controls any relevant legal proceedings. This requirement does not apply in the case of other trustees or bare legal owners.

The second problem arises out of a more recent decision, Rolls-Royce Power Engineering plc v Ricardo Consulting Engineers Ltd [2004] 2 All ER (Comm) 129, [2003] EWHC 2871 (TCC). In that case two companies, A and its parent RRPE, collaborated on the development of a new diesel engine: A handled the contracting and RRPE the actual development. Project consultants engaged by A for RRPE's benefit allegedly botched their job; as a result RRPE suffered loss in carrying out the project. The classic problem thus arose: A, as contractors, had suffered no loss, while RRPE, the sufferers, could not enforce the contract. $A$ and PPRE sought to get round this problem in a number of ways, including an argument that A had contracted as trustees for RRPE and could thus recover substantial damages. HHJ Seymour Q.C., while accepting that a trustee might be able to sue, held that this right was limited to where the other contracting party knew of his status as trustee: where he was not so aware, then the defendant was able to take the "no loss" point.

With respect, this seems a needless limitation on a relatively straightforward doctrine. Suppose a defendant contracts to sell land to a buyer who is actually trustee for someone else, and then fails to make good title. It would be odd if no damages were payable for wasted conveyancing expenses, etc., on the ground that the trustee suffered no loss and the defendant did not know that he was merely contracting as trustee. This is not necessarily to say that the defendant's knowledge (or lack of it) as to the existence of a trust should always be irrelevant. If the loss suffered is not a standardised one, but some consequential damage peculiar to the beneficiary's particular circumstances, then there is much to be said for denying liability. But for ordinary foreseeable losses it is suggested that the trustee ought to be allowed to recover as of course. To the extent that the Rolls-Royce case suggests the contrary, it should, with respect, be regarded as open to reconsideration.

In conclusion, the position as regards a trustee's rights should be simple. Except as regards insolvency and specialised losses referable only to the beneficiary's own position, a trustee should be able to recover losses in the ordinary way without reference to the fact that he is a trustee, which no doubt he will then hold on trust for the beneficiary in the ordinary way.

\section{Andrew Tettenborn}

Bracton Professor of Law, University of Exeter

(C) Andrew Tettenborn 2005 